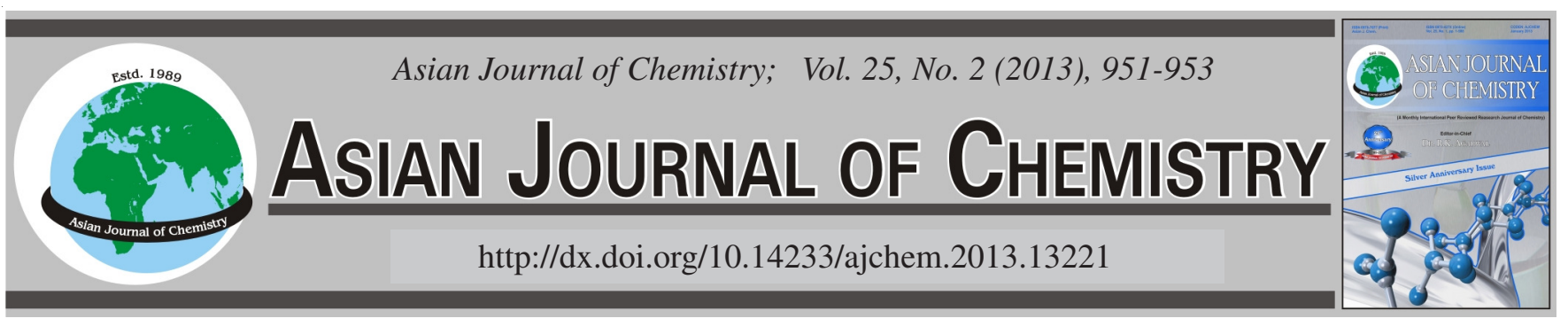

\title{
Study on Treatment Process Improvement of Herbal Drug Wastewater
}

\author{
$\mathrm{JIA} \mathrm{SUN}^{1, *}$, YUE $\mathrm{LI}^{2}$ and Yongming Zhang ${ }^{3}$
}

${ }^{1}$ College of Environmental Science and Engineering, Tongji University, Shanghai 200092, P.R. China

${ }^{2}$ Guangdong Academy of Agricultural Sciences, Guangzhou 510640, P.R. China

${ }^{3}$ Hunan Academy of Building Research, Changsha 410001, P.R. China

*Corresponding author: Tel: +86 150 00432006; E-mail: zixiaorengui@ gmail.com

(Received: 10 December 2011;

Accepted: 27 August 2012)

AJC-12018

\begin{abstract}
Pilot test is made to research the treatment effect of traditional Chinese herbal drug synthetic wastewater by hydrolysis acidification and two-stage biological aerated filter (BAF) on the base of analyzing the reasons that the effluent of existing process failing to reach the standard. The experimental result shows that when the influent COD, SS and colour average $970 \mathrm{mg} / \mathrm{L}, 145 \mathrm{mg} / \mathrm{L}$ and 130 times respectively; those in effluent are $80 \mathrm{mg} / \mathrm{L}, 43 \mathrm{mg} / \mathrm{L}$ and 130 times. The effluent quality conforms to the first class criteria specified in the comprehensive wastewater emission standard.

Key Words: Herbal drug wastewater, Biological aerated filter, Improvement experiment.
\end{abstract}

\section{INTRODUCTION}

Chinese traditional herbal drug wastewater is a kind of organic high concentration wastewater, with a complex composition of such wastewater, high COD/SS concentration, high chromaticity, quality fluctuating, $\mathrm{pH}$ values changing frequently and better biodegrading ability characteristics ${ }^{1}$. There are several methods of treatment for Chinese traditional herbal drug wastewater such as physicochemical, biochemical, chemical and physicochemical-biochemical ${ }^{2-7}$ and biochemical or physicochemical-biochemistry process technology are used in most situation.

The Hengyang Chinese traditional drug factory of Thunis Guhan biopharmaceutical Co. Ltd. is one of key manufacturer in the Chinese pharmaceutical manufacturing enterprises. The design wastewater treatment of the plant wastewater treatment station is $500 \mathrm{~m}^{3} / \mathrm{d}$ and the current actual wastewater treatment is $100-120 \mathrm{~m}^{3} / \mathrm{d}$, by hydrolytic acidification-aeration activated sludge treatment process. As the existing water treatment process can't reach the discharge standards, the research is carried out by applying hydrolytic acidification and two-stage aerated biological filter (BAF) process to deal with the wastewater, achieving a better result and the water quality of effluent satisfies the discharge standards.

Water sources and water quality: The plant use Chinese herbal drugs as raw materials, its synthetic wastewater mainly including the process of washing drugs, soaking drugs in pretreatment workshop (accounting for about $10 \%$ of wastewater), the pre-boiling of original drug and the residue extraction process in extraction workshop (70\%), a small amount of molasses water from tablet workshop (10\%) and the drainage from boiler room (10\%). The quality of the synthetic wastewater in balance tank as follows, COD 300-1600 mg/L, BOD5 $150-850 \mathrm{mg} / \mathrm{L}$, SS 100-250 mg/L, chromaticity multiple 100200, $\mathrm{pH} 4-7$.

Existing wastewater treatment process: The before process of wastewater treatment in the plant wastewater treatment station shown in Fig. 1.

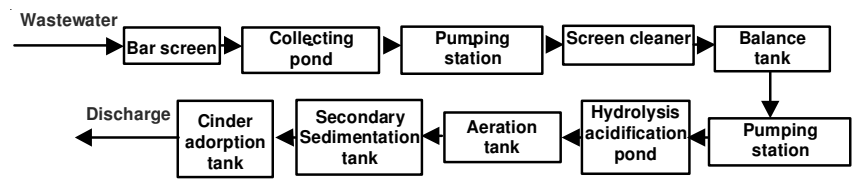

Fig. 1. Before process of wastewater treatment

The effective size of the balance tank is $16 \mathrm{~m} \times 12 \mathrm{~m} \times$ $3.2 \mathrm{~m}, 600 \mathrm{~m}^{3}$ effective volume, $8 \mathrm{~h}$ hydraulic retention time. The effective size of the Hydrolysis acidification pond is 14 $\mathrm{m} \times 10.5 \mathrm{~m} \times 5.2 \mathrm{~m}, 750 \mathrm{~m}^{3}$ effective volume, $10 \mathrm{~h}$ hydraulic retention time, semi soft packing in-built. The effective size of the aeration tank is $12 \mathrm{~m} \times 9 \mathrm{~m} \times 5 \mathrm{~m}, 525 \mathrm{~m}^{3}$ effective volume, $7 \mathrm{~h}$ hydraulic retention time. The effective size of the secondary sedimentation tank is $10 \mathrm{~m} \times 4 \mathrm{~m} \times 4.1 \mathrm{~m}, 2 \mathrm{~h}$ hydraulic retention time.

The integrated wastewater treatment effect of the plant wastewater treatment station is shown in Table-1. 


\begin{tabular}{cccccc}
\hline \multicolumn{7}{c}{ TABLE-1 } \\
INTEGRATED WASTEWATER TREATMENT EFFECT \\
\hline \multirow{2}{*}{ Items } & $\begin{array}{c}\text { COD } \\
(\mathrm{mg} / \mathrm{L})\end{array}$ & $\begin{array}{c}\text { BOD } \\
(\mathrm{mg} / \mathrm{L})\end{array}$ & $\begin{array}{c}\text { SS } \\
(\mathrm{mg} / \mathrm{L})\end{array}$ & $\begin{array}{c}\text { Chromaticity } \\
\text { /multiple }\end{array}$ & $\mathrm{pH}$ \\
\hline Inflow & 990 & 515 & 155 & 150 & 6.45 \\
Discharge & 253 & 111 & 126 & 95 & 7.70 \\
\hline
\end{tabular}

Through the operation of existing processes and water quality analysis, it can be drawn the several following main factors caused wastewater treatment substandard.

Firstly, the wastewater treatment plant failed to run continuously, with stopping and opening frequently. Secondly, the balance ability of the balance tank is in the poor conditioning and large fluctuations in water quality is not conducive to the operation of subsequent treatment process. As the balance tank adopts the Corridor-style layout, the wastewater in the balance tank go forward by plug flow. When the quality of inflow wastewater make great changes, the balance tank would not achieve the role of the buffer and even there would be no protection for the following chemical and biological treatment systems. Thirdly, because of the low concentration of activated sludge in the hydrolysis acidification pond, there are large fluctuations in effluent quality, which lead a large impact to follow-up aeration treatment. Fourthly, the treatment effective of the aeration tank is poor. Because the existing process using the traditional plug-flow activated sludge aeration, the flow in aeration tank go ahead uniformly. The waste water flows in from one side of the pool and flows out from the other side. In this process front-end and back-end flow fluid mixing does not occur. Due to supply oxygen evenly along length direction of the pool, it will appear insufficient oxygen on the entry and excess oxygen on the exit, which drops aerated effect and leads to lower oxygen utilization. Fifthly, secondary sedimentation tank is a little small. The performance of settlement is poor and the suspended solids exceed standard in effluent. Finally, Cinder adsorption tank does not draw out clinker and sludge regularly and it creates the adsorption to be saturated.

\section{EXPERIMENTAL}

Test water from the adjusting tank of the factory waste water treatment station, experiment process flow (Fig. 2).

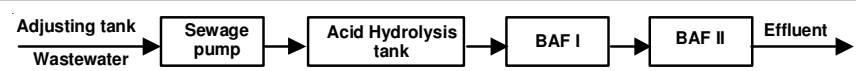

Fig. 2. Improved experimental process flow of wastewater treatment

Hydrolysis acidification tank, used (diameter $\times$ height) $150 \mathrm{~mm} \times 2850 \mathrm{~mm}$ plexiglass columns, built-in YDT elastic stereoscopic packing, loading height of $1900 \mathrm{~mm}$. Water enter from the bottom, out from the top, with hydraulic loading of $0.570 \mathrm{~m}^{3} /\left(\mathrm{m}^{2} \mathrm{~h}\right)$.

One-stage biological aerated filter (BAF I). Used (diameter $\times$ height) $150 \times 3150 \mathrm{~mm}$ plexiglass columns, Built-in ceramic particle size of 4-6 mm, loading height of $2000 \mathrm{~mm}$. Water enter from the bottom, out from the top. Supporting layer of pebbles with diameter of 8-10 mm, loading height of $100 \mathrm{~mm}$. Water distribution by perforated plate, gas distribution by perforated pipe and gas source provided by air compressor. The biological aerated filter designed under the conditions of hydraulic loading of $0.570 \mathrm{~m}^{3} /\left(\mathrm{m}^{2} \cdot \mathrm{h}\right)$ and the air-water ratio of $4: 1$.

Two- stage biological aerated filter (BAF II). Used (diameter $\times$ height) $150 \mathrm{~mm} \times 3000 \mathrm{~mm}$ plexiglass columns, builtin ceramic particle size of 4-6 mm, loading height of 2000 $\mathrm{mm}$. The others conditions are the same with BAF II.

\section{RESULTS AND DISCUSSION}

The system debugged from April 2011, in early May tended to be normal operation. The effluent water quality gradually improved and stabilized. All indexes can meet the emission standards. The average operating data and results from June 10 to August 12 are showed in Tables 2 and 3.

It can be seen from Table-2, the average removal of COD reached $63.2 \%$ in the stage of hydrolysis acidification at the high temperature in summer. Meanwhile, SS and Chroma also have been better removed. The Chinese traditional herbal drug wastewater contains harmless substance and preferably biochemical, but it still contains a certain amount of lignin, alkaloids, tannins and other difficult biodegradable matters. Though the effect of hydrolysis acidification bacteria, the insoluble organic matters and difficult biodegradation of macromolecular substances in wastewater are hydrolyzed into dissolved organic matter and easily biodegradable small molecules, respectively

\begin{tabular}{|c|c|c|c|c|c|c|c|}
\hline \multicolumn{8}{|c|}{$\begin{array}{c}\text { TABLE-2 } \\
\text { OPERATING RESULTS OF EACH PROCESSING UNIT }\end{array}$} \\
\hline \multirow{2}{*}{\multicolumn{2}{|c|}{ Processing unit }} & \multicolumn{2}{|c|}{ COD } & \multicolumn{2}{|c|}{ SS } & \multicolumn{2}{|r|}{ Chroma } \\
\hline & & Density (mg/L) & Removal rate $(\%)$ & Density (mg/L) & Removal rate (\%) & Time & Removal rate (\%) \\
\hline HAT & $\begin{array}{l}\text { Influent } \\
\text { Effluent }\end{array}$ & $\begin{array}{l}970 \\
357\end{array}$ & 63.2 & $\begin{array}{c}145 \\
86\end{array}$ & 40.7 & $\begin{array}{c}130 \\
83\end{array}$ & 36.2 \\
\hline BAFI & $\begin{array}{l}\text { Influent } \\
\text { Effluent }\end{array}$ & $\begin{array}{l}357 \\
136\end{array}$ & 61.9 & $\begin{array}{l}86 \\
55\end{array}$ & 36.0 & $\begin{array}{l}83 \\
53\end{array}$ & 36.1 \\
\hline BAFII & $\begin{array}{l}\text { Influent } \\
\text { Effluent }\end{array}$ & $\begin{array}{c}136 \\
80\end{array}$ & 41.2 & $\begin{array}{l}55 \\
43 \\
\end{array}$ & 21.8 & $\begin{array}{l}53 \\
35\end{array}$ & 34.0 \\
\hline
\end{tabular}

TABLE-3

TOTAL REMOVAL OF THE PROCESS

\begin{tabular}{c|cc|cc|c}
\hline \multirow{2}{*}{$\begin{array}{c}\text { Water } \\
\text { Sampling }\end{array}$} & \multicolumn{2}{|c|}{ COD } & \multicolumn{2}{c|}{ SS } & \multicolumn{2}{c}{ Chroma } \\
\cline { 2 - 6 } & Density (mg/L) & Removal rate (\%) & Density (mg/L) & Removal rate (\%) & Time \\
\hline Influent & 970 & 91.8 & 145 & 70.3 & 130 \\
Effluent & 80 & & 43 & 73.1 & 35 \\
\hline
\end{tabular}


through the hydrolysis acidification bacteria. This process can remove quite part of organics without energy consumption. What's more, after being hydrolysis acidification, the BOD/ $\mathrm{COD}$ ratio is further improved and $\mathrm{pH}$ decreased and these reduce the load and save energy for follow-up aerobic biological treatment. Therefore, the processing unit of hydrolysis acidification plays an extremely important role in the system.

With the increase of temperature, biomembrane in biological aerated filter adapted the character of traditional Chinese herbal drug after a period of acclimation and showed good treatment effect. The average removal of COD was $77.6 \%$, with that of SS $50 \%$ and that of chroma $57.8 \%$ respectively. The experiment results show that two-stage biological aerated filter was effective for COD removal. However, as a result of low concentration of SS and Chroma in influent, the removal of SS and Chroma were not efficient with two-stage biological aerated filter (BAF II, especially) and then it was difficult to reduce the SS and chroma.

COD changes in influent and effluent and the removal rate of COD are showed in Fig. 3.

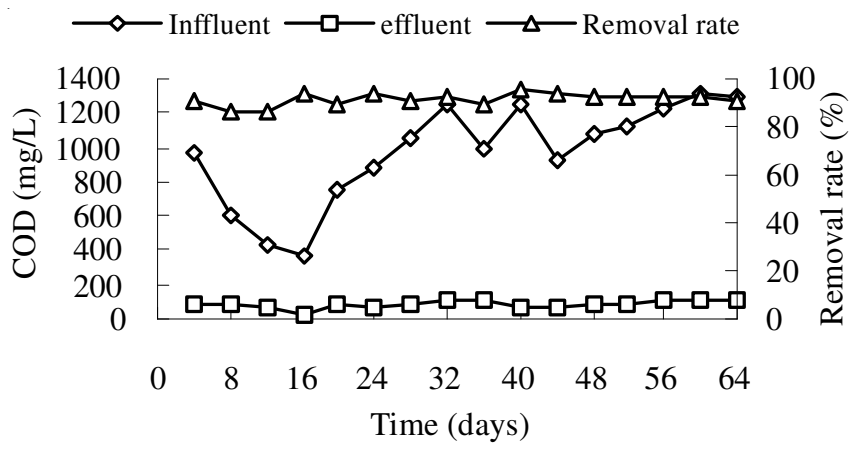

Fig. 3. COD changes in influent and effluent and the removal rate of COD

It can be seen from the Fig. 3 that the influent water quality fluctuates sharply because of intermittent operation of traditional Chinese herbal drug production, with lowest value 357 $\mathrm{mg} / \mathrm{L}$, highest value $1310 \mathrm{mg} / \mathrm{L}$. However, the COD in the effluent around $90 \mathrm{mg} / \mathrm{L}$ and changes little. This shows that this processing system represents strong anti-shock loading capability and suits for the wastewater fluctuates greatly like traditional Chinese herbal drug wastewater.

\section{Conclusion}

Under the conditions of hydraulic loading of $0.570 \mathrm{~m}^{3} /$ $\left(\mathrm{m}^{2} \cdot \mathrm{h}\right)$ and the air-water ratio of $4: 1$, the average quality of effluent was: $\rho(\mathrm{COD})=80 \mathrm{mg} / \mathrm{L}, \rho(\mathrm{SS})=44 \mathrm{mg} / \mathrm{L}$ and Chroma $=35$ times respectively, reaching first-class criteria specified in integrated wastewater discharge standard. Experiment results show that the process is feasible in traditional Chinese herbal drug synthetic wastewater. Hydrolysis acidification and two-stage aerated biological filter is characterized by its simple flow, convenient for managing, strong impulsion load resistance and stable operation, which presents broad applied foreground in such high concentration wastewater treatment.

\section{ACKNOWLEDGEMENTS}

The authors are grateful to the National water pollution control and management technology major projects of China for their support (project number 2009ZX0721-005).

\section{REFERENCES}

1. Z.H. Ding, Technology and Application of Organic Wastewater Treatment, Beijing, p. 23 (2002).

2. Z.Q. Chen, L.V. Bingnan, Z. Sun and H.W. Rong, J. Harbin Univ. C.E. Arch., 16, 198 (2009).

3. A. Nadali, A. Roza, J. Nemat and and A.-A. Babaei, Asian J. Chem., 23, 5220 (2011).

4. X.C. Shu and G. Yang, Environ. Sci. Technol., 20, 321 (2010).

5. H.L. Zheng, T.R. Long and Z.X. Yuan, Technol. Water Treatment, 39, 342 (2010)

6. Y.G. Wang and J. Zhang, Environ. Eng., 14, 214 (2010).

7. A. Singh, A.P. Singh and N. Verma, Asian J. Chem., 23, 5189 (2011). 